\begin{tabular}{lllllllll}
$\mathbf{A}$ & $\mathbf{R}$ & $\mathbf{T}$ & $\mathbf{Y}$ & $\mathbf{K}$ & $\mathbf{U}$ & $\mathbf{E}$ & $\mathbf{Y}$ \\
\hline
\end{tabular}

VOX PATRUM 23 (2003) t. 44-45

Ks. Edward STANIEK

(Kraków, PAT)

\title{
KONCEPCJA HOMILII PATRYSTYCZNEJ
}

W dorobku, jaki zostawili nam Ojcowie Kościoła, duży procent to ich homilie i kazania. Już ten fakt wzywa do zatrzymania się nad tym gatunkiem literackim. W polskich przekładach posiadamy ponad tysiąc tekstów patrystycznych, które są zapisem słowa mówionego ${ }^{1}$. Studia nad tym bogactwem idą w kilku kierunkach. Najczęściej autorzy zatrzymują się nad treścią homilii oraz kazań z punktu widzenia religijnego, moralnego lub historycznego. Innych interesuje warsztat retoryczny. Jeszcze inni uwzględniają filologiczny punkt widzenia.

W referacie podejmuję próbę przedstawienia pewnej syntezy najważniejszych danych dotyczących homilii patrystycznej. Mam na uwadze pomoc w spojrzeniu na homiletyczny dorobek Ojców Kościoła. Z punktu widzenia warsztatowego pragnę zasygnalizować również pytania, które należy postawić, by wejść w bogactwo tego dorobku. O wiele łatwiej zatrzymać się nad Komentarzami, które są esencją powstałą po zalaniu wrzątkiem tekstu natchnionego. Trudniej analizować herbatę - homilię lub kazanie - która z tej esencji jest przygotowana do picia, tym bardziej, że jej stężenie może być bardzo różnorodne, a do tego woda, $z$ jakiej ta herbata powstaje, a którą ludzie żyją na co dzień, w różnych krajach i różnych czasach, często różni się w sposób zasadniczy. A jednak, nie podaje się ludziom esencji, bo wyrządzono by im szkodę $\mathrm{i}$ to poważną. Ewangelia jako pokarm tysięcy ludzi musi być podana w formie słabszej lub mocniejszej herbaty.

Referat opieram na osobistej lekturze homilii i kazań patrystycznych oraz na uwagach, jakie na temat przepowiadania oni podali ${ }^{2}$. Udało mi się w ciągu trzydziestu lat dość dokładnie przeanalizować zarówno z punktu widzenia

' Por. E. Staniek, Seria „Pism Starochrześcijańskich Pisarzy” w rękach kaznodziei, SACh 11 (1995) 35-42.

${ }^{2}$ Klasyczne pozycje to: Augustyn, De doctrina christiana, CCL 32, tłum. J. Sulowski: O nauce chrześcijańskiej, Warszawa 1989; Jan Chryzostom, De sacerdotio, SCh 272, thum. W. Kania: Dialog o kaptaństwie, BOK 1, Kraków 1992; Grzegorz Wielki, Regula pastoralis, SCh 381 i 382, tłum. J. Czuj: Księga Reguty Pasterskiej, POK 22, Poznań 1948. 
treści jak i budowy około tysiąca kazań i homilii Ojców. Trzeba jednak zaznaczyć, że bibliografia prac dotycząca kaznodziejskiego warsztatu Ojców Kościoła jest stosunkowo uboga ${ }^{3}$. Pełne zestawienie tej bibliografii wydaje się być rzeczą ważną i pilną. Ona pozwoli nam na zorientowanie się, co w tym temacie jest zrobionc, a co czeka na opracowanie.

\section{I. ŹRÓDŁA HOMILII PATRYSTYCZNEJ}

Przypominam, że homilia patrystyczna posiada trzy źródła. Pierwszym $z$ nich jest przepowiadanie Ewangelii przez samego Chrystusa. On był Mistrzem nad mistrzami i to zarówno w przekazie treści Dobrej Nowiny, jak i formie jej przekazu. W sensie szerszym źródłem jest całe Pismo Święte, o ile jest czytane przez czlowieka uznającego jego natchnienie. Podkreślam jednak, że przepowiadanie Chrystusa było jedyne i niepowtarzalne, ponieważ On nie był pośrednikiem Słowa Bożego, lecz samym Słowem Boga. Mówiąc o homiliach Ojców Kościoła mamy na uwadze przekaz Słowa Bożego przez pośrednika. Ono jest formą komunikacji, której treścią jest Jezus Chrystus, Odwieczne i Wcielone Słowo Prawdy.

Drugim źródłem homilii starożytnej były wzory przepowiadania w synagogach żydowskich. Do naszych czasów nie zachowały się żadne $z$ tych przemówień. Kto wie, czy wolno je było notować. Istnieją publikacje na temat tego przepowiadania, ale $\mathrm{z}$ reguły mają one na uwadze precyzowanie specyfiki tych wypowiedzi $z$ punktu widzenia warsztatowego. Nic spotkałem natomiast próby określenia czym w samym nabożeństwie synagogalnym, odprawianym najczęściej w dniu szabatu, było przemówienie. Wiadomo tylko, że w tej liturgii istotne były trzy elementy: modlitwa, czytanie Prawa i Proroków oraz przemówienie. Może jaśniej sens tego pytania ujawni się, gdy dotknę charyzmatycznego wymiaru homilii patrystycznej.

Trzecim źródłem homilii Ojców Kościoła były schematy mów wypracowane w warsztatach retorów greckich i rzymskich. Te koncepcje zaczynają odgrywać coraz ważniejszą rolę, w miarę, jak wśród głoszących homilie pojawiają się ludzie wykształceni, czyli dobrze operujący zasadami retoryki.

${ }^{3}$ Por. K. Panuś, Zarys historii kaznodziejstwa w Kościele, cz. 1: Kaznodziejstwo w Kościele powszechnym, Kraków 1999, 31-125 (Starożytność chrzescijańska i wczesne średniowiecze); A. Eckmann, Sztuka wymowy w teorii i praktyce św. Augustyna, w: Stowo Boga i drogi czlowieka. Księga pamiqtkowa ks. bp. Jana Szlagi, Tczew - Pelplin 1998, 155-174. Dużo uwag można znaleźć we wstępach do tłumaczeń homilii i kazań Ojców Kościoła. Czasem podają je autorzy monografii wybitnych Ojców Kościoła. Wciąż jednak jest to wiedza malo uporządkowana. Duzo światła na przepowiadanie Ewangelii w pierwszych wiekach rzuca Historia teologii, t. 1: Epoka patrystyczna, red. A. di Berardino - B. Studer, Kraków 2003, zwlaszcza: P. Grech, Początki teologii chrześcijańskiej, tamże ss. 39-116; B. Studer, Eruditio veterum, tamże ss. 355-380. 


\section{HOMILIA - KAZANIE}

Ustalenie granicy między homilią a kazaniem nie jest łatwe. Wydaje się, że przebiega ona na styku głoszenia Dobrej Nowiny w oparciu o warsztat i język biblijny, co charakteryzuje homilię, oraz w oparciu o warsztat i język retoryczny, co jest właściwe dla kazania. Im więcej autor liczyl się z warsztatem retora, tym bardziej jego homilia stawała się kazaniem. Rzecz jasna traktuję to jako hipotezę, ale po długim zastanowieniu i uważnym wysłuchaniu wielu dyskusji, na temat różnicy miedzy kazaniem a homilią, doszedłem do takiego właśnie wniosku.

1. Język homilii. Dotykam sprawy ważnej, czyli pytania o sposób przekazu Ewangelii. Doskonale wiadomo, że ewangeliczne prawdy można przekazywać na wiele sposobów. Można to uczynić językiem prawnika (tym językiem często posługuje się Urząd Nauczycielski Kościoła), można to czynić językiem filozofa, historyka, poety, dziennikarza, apologety. Określony język jest używany przez głoszącego albo $z$ tej racji, że on sam dobrze nim wlada, albo jest on próbą dotarcia do odbiorców, poniewaź oni się nim posługują. Po dwudziestu wiekach wiemy, jak wiele kłopotów z powodu tego języka i jego komunikatywności miała zarówno Ewangelia, jak i ludzie, którzy ją głosili. Wystarczy wspomnieć spory teologiczne, w których chętnie sięgano po język filozofii lub prawa. Sęk tkwi w tym, że żaden z języków, jakimi posługuje się tylko pewna część ludzi, nie nadaje się do przekazu całej Ewangelii. Język wybranej grupy pozwala tylko na cząstkowy jej przekaz. Dlatego Ewangelia posiada swój język, czyli własny sposób przekazu prawdy objawionej. I tylko ten, kto potrafi opanować ten ewangeliczny język, jest w stanie przekazać całość Dobrej Nowiny.

Po tym wyjaśnieniu zaznaczam, że $\mathrm{z}$ homilią mamy do czynienia wówczas, gdy kaznodzieja posługuje się językiem ewangelicznym ${ }^{4}$. Jeśli sięga do innego języka, czyli przekazuje prawdę objawioną nie licząc się z językiem Ewangelii, trudno jego przekaz nazwać homilia, można natomiast nazwać kazaniem. I tu pojawia się zasadnicze pytanie o to, w jakiej mierze w homilii może być wykorzystany warsztat starożytnego retora, który miał swój własny język. W pierwszych pokoleniach chrześcijan był on postrzegany jako zagrożenie dla samej Ewangelii. Widziano w nim niebezpieczeństwo sekularyzacji homilii. Gdyby bowiem autor zupelnie odrzucił ewangeliczny sposób przekazu, wyleje dziecko z kąpielą. Nie da się przekazywać ewangelicznych treści, przy całkowitej rezygnacji $\mathrm{z}$ ewangelicznego sposobu przekazu.

${ }^{4}$ Cenną pozycją, która pomaga w rozumieniu języka Biblii w ujęciu Ojców Kościoła jest studium: M. Simonetti, Między dostownościq a alegoriq, thum. T. Skibiński, Kraków 2000. Autor nie eksponuje jednak specyfiki języka homilii. Interesuje się sposobem rozumienia słów Pisma Świętego, a nie tyle mechanizmami jego komunikacji. 
To niebezpieczeństwo wyczuwali starożytni biskupi, którzy jeszcze w roku 268 ostro, i to na synodzie, zaatakowali Pawla z Samosaty za to, że przepowiadał Ewangelię według schematów czysto świeckich ${ }^{5}$. Według nich taki sposób przekazu jest zabójczy dla Ewangelii, czyli dla objawionej prawdy. Paweł z Samosaty, jak pamiętamy wystąpił po raz pierwszy na podwyższeniu i mówił czekając na oklaski. Jego sposób przemawiania był oparty na zasadach retoryki, której głównym celem było zdobycie poklasku i odniesienie sukcesu. Potępienie Pawła z Samosaty dotyczylo nie tylko jego dogmatycznego błędu, ale sposobu przekazu Ewangelii i co się ściśle $\mathrm{z}$ tym wiąże, mało ewangelicznego stylu jego życia.

2. Przyjacielska rozmowa. Słowem homilia (ó $\mu \lambda i \alpha$, ó $\mu \iota \lambda \varepsilon \tilde{v})^{6}$ Grecy określali przyjacielską rozmowę. Prawie we wszystkich opracowaniach, w imię tego określenia, autorzy kładą nacisk na formę komunikacji z odbiorcą. Tymczasem wiadomo, że homilia patrystyczna nigdy nie była rozmową. Dialogowe kazania pojawią się dopiero później ale i one nie będą miały charakteru rozmowy z odbiorcami kazania. Gdzie zatem jest miejsce na rozmowę $i$ to przyjacielską? Między kim a kim, toczy się ta rozmowa w duchu przyjaźni.

Odpowiedź może być tylko jedna: jest to rozmowa Boga z człowiekiem. To ona jest homilią w sensie ścisłym. Czyli homilia jest to przekaz przez głosiciela Ewangelii rozmowy Boga $\mathrm{z}$ czlowiekiem. I tu dotykamy sprawy bardzo istotnej. Pierwszym etapem powstania homilii jest rozmowa Boga $\mathrm{z}$ kaznodzieją, przeprowadzona przy pomocy Słowa wcielonego w tekst Biblii. Ta rozmowa, czyli Słowo Boga, które dociera do głosiciela, z polecenia Boga ma być przekazane uczestnikom liturgicznego zgromadzenia. Ostatecznie jest to więc przyjacielska rozmowa samego Boga $\mathrm{z}$ uczestnikami zgromadzenia. Przyjacielska, to wcale nie znaczy latwa, miła i radosna. Przyjaciel w trosce o dobro tego, kogo kocha, może mówić twardo, ostro, nawet raniąc po to, aby uleczyć. On nigdy nie mówi tego, czego oczekuje przyjaciel, ale to, co dla przyjaciela jest dobre. Bywa, że podaje łyżkę gorzkiego lekarstwa, ale ono zawsze przywraca siły.

W tej sytuacji wyłaniają się kolejne pytania o istotne składniki patrystycznej homilii. Pytanie o głosiciela, o miejsce i czas jej przepowiadania, pytanie o rolę Pisma Świętego w homilii i wreszcie pytanie o wybór jej tematu.

Przekazicielem słowa Boga musi być człowiek wybrany przez Niego. Może to mieć miejsce albo na podstawie powierzonego mu urzędu, albo na zasadzie udzielonego mu charyzmatu. Nikt inny nie jest w stanie przekazać słowa Bożego. Byłby bowiem samozwańcem i występowałby w swoim własnym imieniu, a nie w imieniu Boga. To podejście precyzowano w Kościele w ciągu trzech pierwszych wieków. Pamiętamy słynną awanturę w Aleksandrii o to, że Ory-

${ }^{5}$ Por. Eusebius, HE VII 30, 9; E. Staniek, Kazanie w starożytności chrześcijaniskiej, w: Fenomen kazania, red. W. Przyczyna, Kraków 1994, 15-27.

${ }^{6}$ Por. M. Brzozowski - B. Nadolski, Homilia, EK VI 1175-1176. 
genes wygłosił homilię w Palestynie nie będąc prezbiterem, i jak następnym razem, by nie narażać się na zarzuty, został przez biskupów Palestyny włączony w grono prezbiterów: dopiero wówczas miał prawo głoszenia homilii. W III wieku na Wschodzie już to wystarczało, ale Zachód długo się bronił przed tym i rezerwował głoszenie homilii wyłącznie dla biskupa. Jeszcze końcem wieku IV, w Kartaginie, Walerian, biskup Hippony, musiał się mocno tłumaczyć z tego, że dopuścił Augustyna, włączonego w grono prezbiterów, do głoszenia homilii w swojej obecności.

Drugim elementem było zgromadzenie liturgiczne. Przemówienia na tematy Ewangelii poza zgromadzeniem były dozwolone, ale nie były homilią. Takie zgromadzenie mogło posiadać albo charakter naszej godziny biblijnej, albo zgromadzenia eucharystycznego. Jedno i drugie miało liturgiczną oprawę. Pierwsze bardziej przypominało zgromadzenie synagogalne. Drugie było połączone $z$ wtajemniczeniem w Eucharystię. Na pewno w okresie patrystycznym nie należy rezerwować pojęcia homilii wyłącznie do przepowiadania w czasie sprawowania Eucharystii. Niestety, nie udało mi się ustalić, z jakich powodów zgromadzenie liturgiczne jako miejsce przepowiadania homilii odgrywało tak wielką rolę. Na pewno w grę wchodzi świadomość prawdy o Kościele. Z tej racji ten element homilii należałoby nazwać eklezjalnym. Odbiorcą słowa Bożego jest zawsze cały Kościół. To nie tylko sprawa grona ludzi zebranych wokół mówiącego. Teoretycznie taki wymiar homilii jest podkreślany przez wszystkie wieki. Okres patrystyczny nie musiał o tym mówić, ponieważ starożytni chrześcijanie wiedzieli co to znaczy być wtajemniczonym w Kościól ${ }^{7}$. Czy jednak ten eklezjalny wymiar byl jedynym, czy może w grę wchodziły jakieś inne wskazania prawne lub liturgiczne, trudno określić.

Kolejnym elementem było Pismo Swięte, a mówiąc jasno jego chrystologiczny wymiar. O homiletycznym sposobie jego odczytywania powiem za chwilę więcej. Tu jedynie sygnalizuję, że ono stanowiło pierwszorzędne tworzywo homilii. To ono było Słowem Bożym w czystej postaci. Głosiciele stosowali dwie metody. Jedna polegała na wprowadzeniu uczestników liturgii w wydarzenie zbawcze opisane na kartach Pisma Świętego. To tak jakby powtarzano wydarzenie, a raczej je uobecniano, aby - łamiąc kod czasu - uczestnicy mogli wziąć w nim udział odnajdując się w biblijnych bohaterach. Tu mistrzem nad mistrzami był i pozostanie na zawsze Orygenes. On przemawia z pozycji wtajemniczającego. W takim ujęciu homilia jest wtajemniczeniem w wydarzenie zbawcze.

I tu powstaje pytanie, które już sygnalizowałem: czy tekst wygłoszonej homilii jest homilią? Orygenes przez wiele lat nie zgadzal się na notowanie homilii ${ }^{8}$,

${ }^{7}$ Dziś przeciętny katolik tego wtajemniczenia nie dostrzega. Ono nawet w \$́wiadomości kaplanów i katechetów rzadko kiedy dochodzi do glosu.

${ }^{8}$ Por. H. Crouzel, Orygenes, thum. J. Margański, Bydgoszcz 1996. Dzieło posiada dobry zestaw bibliografii, w której pewne pozycje dotyczą homilii Orygenesa. 
a czynił to najprawdopodobniej $\mathrm{z}$ tego powodu, ze takiego tekstu nie traktował jako homilii. Tekst homilii jest zatem, jak okaz zasuszony w zielniku lub w gablocie, ale nie ma w nim ducha, który decydował o życiu. Homilia w takim ujęciu jest doświadczeniem obecności Ducha Świętego, który pozostaje w komunikacji ze wszystkimi jej uczestnikami. Do dnia dzisiejszego pewne ruchy charyzmatyczne nie uznają ani homilii w formie tekstu, ani nawet nagranej na taśmę. Ich zdaniem Duch Święty jest i działa w zgromadzeniu, a nie ma Go ani w tekście, ani nie posługuje się On taśmą.

Drugi sposób sięgania do tekstu Pisma Świętego polegał na przekazaniu uczestnikom prawdy religijno-moralnej tak, by mogli według niej kształtować życie. Prawda dogmatyczna lub moralna była na pierwszym miejscu. Tekst Biblii służył do jej wyjaśnienia. Sposobów wykorzystania tego tekstu było wiele, można go bylo cytować. Przy doskonałym opanowaniu pamięci - zwłaszcza słuchowej - cytowano dziesiątki, a nawet setki fragmentów w jednym kazaniu. Dozwolona była parafraza tekstu natchnionego. Im więcej było Biblii, tym cenniejsze było kazanie i tym bliższe homilii.

Wreszcie elementem homilii jest sytuacja życiowa uczestników homilii, czyli aktualność poruszonego w niej tematu. Skoro to jest rozmowa Boga $\mathrm{z}$ czlowiekiem, to Ten doskonale zna sytuację, w jakiej kieruje swoje słowo do uczestników liturgii. Dlatego jest możliwa Jego rozmowa (homilia) ze słuchaczami. Bóg odpowiada na pytania nurtujące uczestników zgromadzenia i rzuca światło na sytuację, w jakiej oni się znajdują. Bierze przy tym pod uwagę zarówno sytuację egzystencjalną, jak i stan ich ducha.

Aktualność homilii nie musi być przez kaznodzieję nazwana po imieniu. Jego słowo dociera do serc słuchaczy i w nich znajduje twórczy rezonans. To Duch Święty posługuje się wypowiedzianym słowem dla ubogacenia każdego z słuchaczy indywidualnie. Dotykam postawy odbiorcy słów homilii, co jednak nie należy do mego tematu.

\section{RODZAJE HOMILII}

Powinienem uwzględnić historyczny rozwój w krystalizowaniu warsztatu starożytnych mówców kościelnych, co pozwoliłoby na śledzenie tego, co $\mathrm{z}$ punktu widzenia hierarchii wartości jest najważniejsze. Pierwsze bowiem homilie były najbliższe ducha Apostołów, i to, co w nich jest - tak z punktu widzenia treści, jak i formy - winno być zawsze zachowane. Sledzenie tego rozwoju nie jest latwe, a w otwieraniu bogactwa tekstów, jakie posiadamy nie jest najważniejsze. W tej sytuacji zdecydowałem się na zasygnalizowanie trzech rodzajów homilii, $\mathrm{z}$ jakimi mamy do czynienia w okresie patrystycznym.

1. Homilia jako wtajemniczenie. Fakt, że niewiele tekstów homilii I i II wieku zachowało się do naszych czasów, można tłumaczyć albo wspomnianą 
już niechęcią do zapisywania słowa Bożego traktowanego jako wydarzenie zbawcze, albo ich niskim poziomem w zestawieniu $\mathrm{z}$ tym, na jakim pod koniec swego życia ustawił homilię Orygenes ${ }^{9}$. Uczestnicy jego homilii niejako wymusili na nim pozwolenie na zapis głoszonego słowa i na korektę tekstu. Ostatecznie zgodził się na jedno i drugie, i puścił w obieg ich tekst. W sporach, jakie toczyły się wokól Orygenesa i jego poglądów, duża ilość jego homilii zaginęła, ale na szczęście część dotarła do naszych czasów.

Orygenes traktuje tekst Pisma Świętego jako nową postać wcielenia Syna Bożego. Słowo Biblii jest szatą Syna Bożego, podobnie jak Jego ludzkie ciało, i podobnie jak Kościól. Wiara w obecnego w Piśmie Świętym Chrystusa jest nieodzownie potrzebna do wtajemniczenia w jego bogactwo. Gdy ktoś tej wiary nie posiada, nie ma klucza, i bogactwo ducha jest dla niego zamknięte.

Jako kaznodzieja Orygenes traktował Pismo Święte jako boski instrument muzyczny, na którym można wygrywać nieprawdopodobnie piękne melodie trafiające wprost w serce i umysł grającego oraz w serca uczestników koncertu. Te melodie wydobyte $\mathrm{z}$ instrumentu to objawienie samego obecnego $\mathrm{w}$ nim Logosu. Homilia to koncert karmiący ducha. To pieśń, w której jest obecny sam Chrystus. Trzeba dobrze znać sam instrument, to jest pierwszy warunek. Orygenes studium samego instrumentu traktowal jako ustalanie sensu literalnego. Cenił ten sens bardzo wysoko i nigdy go nie lekceważył. Zapomnienie o tym, jest równoznaczne z niedocenianiem jego Heksapli. A jej sporządzenie było wielkim dziełem Orygenesa i warsztatem jego biblijnych studiów.

Drugim elementem było opanowanie reguł gry na instrumencie, czyli pewnego rodzaju rzemiosłem dostępnym dla każdego, komu na tej nauce zależało. Homilie traktowal jako pokarm ducha dla wiernych i jako zachętę do czytania tekstu natchnionego. Ten drugi cel sprawiał, że podaje w nich wiele wyjaśnień potrzebnych do lektury Biblii. Ponieważ wchodzenie w jej bogactwo jest uzależnione od doskonalenia życia religijno-moralnego, Orygenes w swoich homiliach kładl nacisk głównie na te wątki.

Nikt jednak nie ma co do tego żadnych wątpliwości, że aby być muzykiem, nie wystarczy samo rzemiosło, lecz potrzebny jest talent, czyli dar wyjątkowy udzielany przez Boga nielicznym. Podobnie jest z umiejętnością odczytywania Pisma Swiętego. Potrzebny jest do tego specjalny charyzmat. Orygenes tak traktował swe powołanie, zarówno jako biblijnego teologa, jak i kaznodziei. Był świadom otrzymanego od Boga charyzmatu. Wiedział, że ten dar został mu dany nie tyle dia niego, ile dla całego Kościoła. Na pewno dar ten jest potrzebny dla odczytania tekstu natchnionego. Czy Orygenes dostrzegał również potrzebę charyzmatu w przekazie prawdy objawionej w formie homilii, tego nie

${ }^{9}$ Cenne uwagi na temat homiletycznego podejścia Orygenesa podaje o. Emil Stanula we wstępach do kilku tomów PSP, zawierających tłumaczenia homilii Mistrza z Aleksandrii, jak PSP 30, 5-20; PSP 23, 34-56; PSP 24, 14-18; PSP 34, 9-29. 
potrafię powiedzieć. Może refleksja nad koncepcją biblijnego komentarza w ujęciu Orygenesa pomoże sprecyzować odpowiedź na to pytanie. Komentarz bowiem $w$ jego rozumieniu jest zarezerwowany dla wtajemniczonych i posiada charakter elitarny. Mocno podkreślam, że należy zawsze pamiętać o tym, ze Orygenes jest gnostykiem, a gnostyckie podejście jest oparte na wtajemniczeniu i stopniach wtajemniczenia. Dla aleksandryjskiego Mistrza homilia jest jednym $z$ niższych stopni wtajemniczenia.

W homiletycznym przekazie są potrzebne dwa charyzmaty. Jeden polegający na umiejętności wejścia w bogactwo Pisma św., i drugi potrzebny do komunikacji tego bogactwa $\mathrm{z}$ odbiorcami, czyli $\mathrm{z}$ uczestnikami homilii. To rozróżnienie występuje jasno u św. Grzegorza Teologa, czy jest u Orygenesa, tego nie wiem. W praktyce można otrzymać tylko pierwszy charyzmat, czyli rozumienia tekstu natchnionego, i nie otrzymać drugiego, czyli przekazu jego bogactwa. Występuje to u pewnych mistyków, którzy nie są powołani do przekazu bogactwa objawienia innym, a poznanie prawdy objawionej przez nich jest potrzebne do dobrego wykonania zadań, jakie im Bóg zleca.

Można wyróżnić dwa ujęcia homilii Orygenesa. W jednych wprowadzał uczestników w jakieś wybrane wydarzenie biblijne. Czynił to na zasadzie komentarza do małych fragmentów. Tak są zbudowane między innymi Homilie na Ewangelie św. Łukasza. Inne posiadają charakter klucza potrzebnego do odkrycia bogactwa danej księgi. Przykładem mogą być Homilie do Księgi Pieśni nad pieśniami. Homilie Orygenesa są nutowym zapisem koncertów, jakie słuchano w jego wydaniu, tak zdumiewająco bogate, że w zestawieniu $\mathrm{z}$ nimi inne bledną, a nawet nikną. Ktokolwiek szuka odpowiedzi na pytanie, czym była w starożytnym Kościele homilia, ten znajdzie ją w uważnym studium homilii Orygenesa. On też w wielkiej mierze zaważył na podejściu do homilii w dalszych dziejach Kościoła.

2. Homilia jako komentarz. Nieco inne podejście do homilii posiadał Jan Chryzostom ${ }^{10}$. On nie głosił homilii $z$ łodzi ortodoksyjnego gnostyka. On miał przed sobą tłumy, które wypełniały Kościół tratując po drodze stopnie wtajemniczenia. Jeszcze w jego czasach podjęto wielką bitwę o zachowanie tych stopni. Uczyniono to w katechezach skierowanych do katechumenów i do neofitów. Te pierwsze mają na uwadze wtajemniczenie w prawdę objawioną. Należałoby je z punktu widzenia kaznodziejskiego dokładniej omówić. Niektóre $z$ nich są zbudowane prawie wyłącznie $z$ tekstów biblijnych. Mam na uwadze głównie Katechezy Cyryla Jerozolimskiego, a ich kośćcem jest ówczesne Credo. Tekst biblijny jest narzędziem wyjaśnienia bogactwa Wyznania Wiary. Czy jest to homilia w sensie ścisłym, oto pytanie otwarte.

${ }^{10}$ Zasadnicze ustawianie kaznodziejskiego podejścia podaje sam Chryzostom w Dialogu o kapłaństwie, Kraków 1992. Cenne uwagi o jego kaznodziejstwie podaje J.N.D. Kelly. Zlote usta. Jan Chryzostom. Asceta, kaznodzieja, biskup, thum. K. Krakowczyk, Bydgoszcz 2001. 
Inny charakter posiada wtajemniczenie w obrzędy sakramentalne, czyli kazania mistagogiczne. I w nich tekst Pisma Świętego jest tworzywem numer jeden, ale wtajemniczenie idzie bardziej po linii odkrywania symboliki liturgicznej, niż samego tekstu. W jakiej mierze są to homilie, oto kolejne pytanie. Jan glosil w Antiochii katechezy i należy do tych, którzy przyczynili się do krystalizacji tej formy przepowiadania.

Masowość chrztu nie pozwoliła na ocalenie pieczęci wtajemniczenia. Jej wartość została zdewaluowana. Złotousty miał przed sobą rzesze ochrzczonych, których życie było dalekie od ewangelicznych ideałów. Dodatkowo uczestnicy wysoko cenili kunszt wymowy. Oklaskiwali jedynie wielkich mówców, nawet niezależnie od tego, co mówili, byle mówili pięknie. Samo piękno wymowy wysunęlo się na pierwszy plan. Jan ukończył studia retorskie z odznaczeniem. Libaniusz dostrzegl jego wyjątkowy talent w dziedzinie krasomówstwa. Mógł stanąć w szranki z najlepszymi mówcami ówczesnego świata. Postanowił to uczynić. Problem był jeden, ten, o który potknął się Paweł z Samosaty. Jak wykorzystać warsztat retora nie naruszając ewangelicznego przekazu Dobrej Nowiny? Jan uznał, że najważniejszymi elementami przekazu ewangelicznego są prostota, wierność prawdzie i miłość. Przez to potrójne sito przelał wszystkie wskazania sztuki wymowy, jakie otrzymał od Libaniusza i podpatrzył u innych mistrzów.

Prostota stylu pozwoliła mu dotrzeć z treścią do każdego słuchacza. Najlepsze pod tym względem są jego Homilie do Ewangelii św. Mateusza ${ }^{11}$, uważane powszechnie za arcydzieło sztuki homiletycznej. Ponieważ zachował w nich tonację przyjacielskiej rozmowy, prostota nie pozwalała mu wchodzić na niepotrzebne retoryczne drabinki, na których popisywał się sam mówca i często był oklaskiwany jako znakomity akrobata słowa. Jan chcial, aby w jego homilii oklaskiwany był Chrystus, a nie on sam. Aby uwaga słuchaczy była skoncentrowana na Jezusie, a nie na kaznodziei. W usunięciu się w cień pomagało mu umiłowanie prawdy. To ona była ważna. W przemówieniach retorów istniało niebezpieczeństwo przerostu formy nad treścią. W homiliach Jana to niebezpieczeństwo się nie pojawia. Nie ustrzegli się go inni starożytni mówcy nawet tak wielkiej klasy, jak św. Augustyn, który raz po raz wywinie kilka numerów na retorycznych drabinkach, po czym schodzi, by dalej kontynuować swą mowę według zasad ewangelicznej prostoty.

Umiłowanie prawdy pozwalało oczyścić przemówienie $z$ wszelkich naleciałości filozofii wypracowanej w różnych szkołach starożytnych. Wiadomo, że pytanie o prawdę stanowiło most, na którym chrześcijanie spotykali się z filozofami. Jan nie ma wątpliwości co do tego, że Ewangelia jest najwyższą i najdoskonalszą filozofią, ponieważ jest zbudowana $z$ samej prawdy. Nie interesuje go filozofia jako system, ale jako sposób życia. On głosi filozofię,

${ }^{11}$ Homilie na Ewangelie wedlug św. Mateusza, t. 1-2, ŹMT 18 i 23, Kraków 2000 i 2002. 
ale dla niego to słowo jest równoznaczne ze słowem - Ewangelia; ona bowiem jest najdoskonalszą filozofią.

Najważnicjszą zasadą w przekazic ewangelicznym jest jednak - według Chryzostoma - miłość. Jan rozumic całość historii zbawienia jako dziejc miłości Boga do człowicka i szkołę, w której Bóg uczy ludzkość sztuki miłości w różnych jej wymiarach. Dlatego miłość stanowi klucz, którym on otwicra wszystkic biblijne teksty. Dla Jana nawet najwiçksze kary, jakie Bóg zesłał za ludzkie grzechy, są przede wszystkim dzicłem Jego miłości, czyli autentycznej troski o dobro człowieka. Śledzenic tego wątku w homiliach Jana jest pasjonujące. To jest to, czego często brakuje innym mówcą. A wiele świadczy o tym, ż z chwilą, gdy znika on z pola widzenia kaznodziei, jego przemówienie wychodzi poza świat Ewangelii.

Jan w swoich homiliach wyniósł na ambonę systematyczny komentarz do wielu ksiąg Pisma Świętcgo. Wyjaśniał słuchaczom księgę po księdze, zdanie po zdaniu, często słowo po słowic. To podejście broniło go przed powtarzaniem. On, podobnic jak Orygenes, był sługą natchnionego tekstu. Korzystał z możliwości ciąglcgo czytania Pisma Świętego na zgromadzeniach liturgicznych, co pozwalało słuchaczom przygotować się do odbioru jego słowa. Oni mogli w domu przeczytać kolejny fragment, który wyjaśniał w homilii. To ułatwiało komunikację, a równocześnic zamieniało homilic w szkołę czytania tekstu biblijnego.

O odwadze Jana świadczy fakt, że wyjaśnił językiem kaznodzici Listy św. Pawła, które - jak nam dobrze wiadomo - są bardzo trudne. Nie wiem, czy na przestrzeni wieków istnicje drugi taki śmiałek, który by w formie homilii wyjaśnił zwykłym wiernym Listy Apostoła Narodów. Mój podziw dla niego jest tym wiçkszy, że uczestnicy jego homilii i kazań coraz mniej rozumieli potrzebę wtajemniczenia, a doktryna Pawła wymaga tego, jako koniecznego warunku.

Jeden element $z$ Listów Pawła Chryzostom wykorzystał prawie we wszystkich homiliach. Ich ostatnia część zawsze była poświęcona tematyce moralnej, najczęściej w ujęciu kazuistycznym. Szczególnie lubil malować wady swoich słuchaczy. Ponicważ czyni to $z$ milością, nawet bardzo ostre sformułowania ani nic gorszyły maluczkich, ani nie dobijały winnych. Oni wiedzieli, że mówi do nich lekarz zatroskany o ich duchowe zdrowie.

3. Homilie Paschalne. Jedna z najstarszych zachowanych homilii jest dzicłem Melitona z Sardes. Jest ona pieśnią wielbiącą Boga za tajemnicę wybawicnia z grzechu, śmierci i niewoli szatana. Oparta jest na typologii biblijnej, która pozwala na ukazanie bogactwa tajemnicy paschalnej jako centralnego wydarzenia w dziejach świata. Autor doskonale zna dzieje biblijne. Podaje wielką ilość imion i wydarzeń z historii Starego Testamentu. Jego Homilia jest ułożona z tekstów Pisma Świętego. Nie jest jednak wyjaśnieniem jednego fragmentu, jest wędrówką przez dzieje zmicrzającą wyraźnic do wprowadzenia uczestników 
homilii w tajemnicę męki, śmierci i zmartwychwstania Jezusa, czyni to jednak nie tyle w wymiarze biblijnym, ile w wymiarze liturgicznym. To jest pieśń, która stanowiła ważny element liturgii Wielkiej Soboty. Kilka innych homilii paschalnych wznosi się na podobny poziom, między innymi słynna dialogowana Homilia, w której autor przedstawia rozmowę Jezusa z Adamem w krainie śmierci. Czytamy ją w brewiarzu w Wielka Sobotę. Pojawia się tu po raz kolejny pytanic o związek wtajemniczenia w Biblię, z wtajemniczeniem w liturgię.

Piękno i bogactwo tych paschalnych homilii świadczy o randze, jaką w życiu starożytnego Kościoła posiadała uroczystość wielkanocna. Z punktu widzenia historycznego powinienem rozpocząć od omówienia Homilii Melitona z Sardes i pozostałych homilii paschalnych, ale ponieważ jest to homilia jednego dnia, uznałem za stosowne wspomnieć o niej dopiero po przedstawieniu homilii dnia powszedniego w wydaniu Orygenesa i Jana Chryzostoma. Różnica jest taka, jak między chlebem codziennym a świątecznym ciastem.

Homilie paschalne otwierają drzwi w stronę homilii mistagogicznych, które częściej noszą nazwę katechez. Zawsze jednak oddziela się je od pouczeń przeznaczonych dla katechumenów, zaznaczając w ten sposób ich jakościową odrębność. Celem homilii mistagogicznych było głębsze wtajemniczenie w sakrament chrztu, bierzmowania i Eucharystii. Te katechezy również aż do osiemdziesiątych lat wieku IV były opatrzone pieczęcią tajemnicy. Najczęściej spotykane tłumaczenie sprowadza się do wskazania, iż mogli w nich uczestniczyć jedynie wtajemniczeni. Nie jest to jednak tłumaczenie wystarczające. Justyn w połowie II wieku opisał dość dokładnie obrzęd chrztu i Eucharystii nie obawiając się złamania pieczęci wtajemniczenia. Uczynił to jednak w Apologii, a nie w homilii mistagogicznej. Wydaje się, że i tu z punktu widzenia teologicznego mamy do czynienia $z$ homilią czy katechezą, wygłoszoną w zgromadzeniu świętym, która była niepowtarzalnym dziełem Ducha Świętego i dlatego jej tekst nie mógł być przekazywany poza uczestników zgromadzenia. Dlaczego w latach osiemdziesiątych IV wieku odstąpiono od tego, i równocześnie w Jerozolimie, Antiochii, oraz w Mediolanie spisano katechezy mistagogiczne, pozostaje dla mnie tajemnicą. Podobnie jak w III wieku w odniesieniu do homilii, tak w IV wieku w odniesieniu do kazań mistagogicznych zdecydowano się na przekaz ich tekstu wiedząc, że on jest bez życia, jest kolejnym eksponatem w skansenie Kościoła.

$* * *$

Wiem, że dla patrologa temat referatu jest ważny. Ostatecznie otwierając homilie i kazania Ojców Kościoła stoimy na brzegu rozległego morza. Jego bogactwo jest wprost nieogarnione i trzeba się po nim w jakiś sposób poruszać. Zdaję sobie również sprawę $\mathrm{z}$ tego, że $\mathrm{w}$ tak wybranym gronie nie powiedziałem nic nowego. Przypomniałem jedynie pewne sprawy celem umożli- 
wienia rozmowy na temat homilii patrystycznej. Nie podjąłem tematu kazania. Sądzę, ze ustalenie jego zasad oraz sprecyzowanie przynajmniej w pewnej mierze rodzajów kazań, jakie pojawiają się w starożytnym Kościele, byłoby dla nas pożyteczne. Nie ulega bowiem żadnych wątpliwości, że mowy pogrzebowe w wydaniu Ambrożego czy Grzegorza z Nyssy, albo mowy ku czci swiętych, nawet samego Jana Chryzostoma, nie są homiliami. Ich założenia są inne. Podobnie rzecz się przedstawia $\mathrm{z}$ kazaniami moralnymi, apologetycznymi, czy dogmatycznymi.

Wybrałem taki, a nie inny sposób ujęcia tego tematu, mając na uwadze wskazanie spraw najważniejszych, czyli przypomnienie zasad dotyczących homilii Ojców Kościoła. Pragnę też zachęcić do podejmowania tematów w oparciu o dostępne homilie starożytne, zwłaszcza prac magisterskich. Kontakt $z$ tymi tekstami, mimo że są one - jak sugeruję w formie hipotezy - skansenem zycia starożytnego Kościoła, może dać wiele. Mam na uwadze szczególnie studentów, których zadaniem życiowym będzie przepowiadanie Ewangelii.

Uważam, że warunkiem ich właściwego odczytania jest wiara w natchnienie tekstu biblijnego oraz opanowanie tego, co nazywam językiem Ewangelii. Kto tego języka nie zna, nie jest w stanie odczytać homilii Ojców Kościoła. Orygenes przypomina, że wejście w bogactwo Biblii dokonuje się drogą stopniowego wtajemniczenia. Jan Chryzostom domaga się od głoszącego homilię prostoty języka (nie prostactwa!), wierności prawdzie oraz miłości Boga i słuchaczy. Zanim zdecydujemy się na zdobywanie himalajskich szczytów przepowiadania Ewangelii, trzeba podziwiać je $z$ oddali i pilnie śledzić każdy ruch mistrzów, którzy już w starożytności je zdobyli.

\section{IL CONCETTO DELL'OMELIA PATRISTICA}

(Riassunto)

L'omelia patristica è l'entrare nella richezza del mondo divino, il quale si effettua per mezzo dell'iniziazione alla Sacra Scrittura. L'omelia era intesa come l'evento salvifico irrepetibile che teneva luogo nell'asemblea liturgica. Similmente l'omelia era intesa nella Sinagoga d'Israele. I testi patristici delle omelie, che sono pervenuti ai nostri tempi, sono quasi „una partitura" del canto fatto dai maestri antichi della predicazione della parola di Dio.

Origene di fronte alla comunità teneva molto al carattere mistagogico delle omelie. Giovanni Crisostomo predicando alle folle dei cristiani, spesso di una fede debole, intendeva l'omelia piuttosto come il commento alla Sacra Scrittura che l'iniziazione mistagogica. 